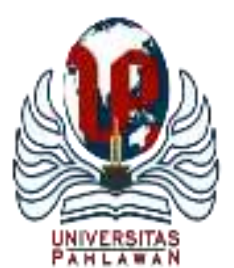

Edukatif : Jurnal Ilmu Pendidikan Volume 3 Nomor 6 Tahun 2021 Halm 4102 - 4107 EDUKATIF: JURNAL ILMU PENDIDIKAN

Research \& Learning in Education

https:/ledukatif.org/index.php/edukatif/index

\section{Evaluasi Penghapusan Ujian Sekolah Berstandar Nasional (USBN)}

\section{Okhaifi Prasetyo $^{1 凶}$, Amanda Ridho Pratomo ${ }^{2}$}

Pendidikan Sejarah Program Magister, Universitas Negeri Yogyakarta, Indonesia ${ }^{1}$, Pendidikan Luar Sekolah Program Magister, Universitas Negeri Yogyakarta, Indonesia ${ }^{2}$

E-mail : okhaifiprasetyo.2019@ student.uny.ac.id ${ }^{1}$, amandaridho.2019@ student.uny.ac.id ${ }^{2}$

\begin{abstract}
Abstrak
Ujian Sekolah Berstandar Nasional (USBN) adalah kegiatan pengukuran capaian kompetensi peserta didik yang dilakukan Satuan Pendidikan dengan mengacu pada Standar Kompetensi Lulusan untuk memperoleh pengakuan atas prestasi belajar. Untuk itu tujuan penelitian ini yaitu mengevaluasi penghapusan ujian sekolah berstandar nasional (USBN). Penelitian ini merupakan studi literatur dengan menelaah sumber-sumber terkait penghapusan ujian sekolah berstandar nasional (USBN). Hasil dari berbagai telaah literatur ini akan digunakan untuk mengevaluasi penghapusan ujian sekolah berstandar nasional (USBN) serta potensi penelitian selanjutnya di Indonesia. Pelaksanaan USBN bertujuan untuk mengukur pencapaian hasil belajar peserta didik selama di sekolah dasar dan menengah. Alasan Mendikbud Nadiem menghapus USBN, karena materi dinilai terlalu padat sehingga cenderung mengajarkan materi dan menghafal materi, bukan kompetensi. Selain itu USBN juga membuat peserta didik dan guru stres, dan hal itu mengubah indikator keberhasilan siswa sebagai individu. Banyak pihak yang setuju dengan penghapusan USBN, hanya saja perlunya perbaikan yang dilakukan pihak pendidikan untuk pengganti USBN.
\end{abstract}

Kata Kunci: USBN, Evaluasi Penghapusan.

\begin{abstract}
The National Standard School Examination (USBN) is an activity to measure the achievement of student competencies by the Education Unit by referring to the Graduate Competency Standards to gain recognition for learning achievement. For this reason, the purpose of this study is to evaluate the abolition of the National Standard School Examination (USBN). This research is a literature study by examining sources related to the dissolution of the national standard school exam (USBN). The results of these various literature reviews will be used to evaluate the abolishment of the National Standard School Examination (USBN) and the potential for further research in Indonesia. The implementation of USBN aims to measure the achievement of student learning outcomes during elementary and secondary schools. The Minister of Education and Culture Nadiem deleting USBN was because the material was considered too dense, so it tended to teach material and memorize material, not competence. In addition, USBN also stresses students and teachers, and it changes the indicators of student success as individuals. Many parties agree with the abolition of USBN, and it's just that the education sector needs improvements to replace USBN.
\end{abstract}

Keywords:USBN, Evaluation of Deletion.

Copyright (c) 2021 Okhaifi Prasetyo, Amanda Ridho Pratomo

Corresponding author

Email : okhaifiprasetyo.2019@student.uny.ac.id

DOI : https://doi.org/10.31004/edukatif.v3i6.1281 
4103 EVALUASI PENGHAPUSAN UJIAN SEKOLAH BERSTANDAR NASIONAL (USBN)- Okhaifi Prasetyo, Amanda Ridho Pratomo

DOI: https://doi.org/10.31004/edukatif.v3i6.1281

\section{PENDAHULUAN}

Pendidikan merupakan hal penting dan memerlukan perhatian serius. Peningkatan mutu pendidikan merupakan tuntutan utama di jaman sekarang ini, salah satunya melalui kritikan (Waruwu, 2021:3722). Banyak kritikan dari praktisi pendidikan, akademisi dan masyarakat yang sering dilontarkan kepada sistem pendidikan. Kritik tersebut sangat komplek, di mulai dari sistem pendidikan yang berubah-ubah ketika ganti menteri pendidikan, kurikulum yang kurang tepat dengan mata pelajaran yang terlalu banyak dan tidak berfokus pada hal-hal yang seharusnya diberikan, dan lain sebagainya, namun demikian, masalah sering menjadi perhatian setiap sistem pendidikan problem evaluasi yang kurang efektif (Farida, 2000:1). Menurut Ngalim(1994:4) kritik dari berbagai pihak terkait evaluasi pendidikan merupakan hal yang wajar, sebab evaluasi merupakan kerangka dasar untuk mengetahui kualitas dan mutu pendidikan. Hal ini dikarenakan, evaluasi sangat terkait dengan keseluruhan proses belajar mengajar, tujuan pengajaran dan proses belajar mengajar. Evaluasi belajar mengajar merupakan bagian dalam proses pendidikan. Evaluasi pencapaian belajar pesera didik tidak hanya menyangkut aspek-aspek kognitifnya saja, tetapi juga mengenai aplikasi atau performance, aspek efektif yang menyangkut sikap serta internalisasi nilai-nilai yang perlu ditanamkan dan dibina melalui mata pelajaran yang diberikanya.

Rendahnya mutu pendidikan di Indonesia masih menjadi masalah bagi bangsa ini. Adapun usaha pemerintah dalam meningkatkan mutu pendidikan saat ini adalah dengan mengembangkan sistem penilaian hasil belajar menggunakan seperangkat soal-soal tes yang berlaku secara nasional pada akhir suatu jenjang pendidikan, disamping penilaian yang dilakukan oleh pendidik di sekolah dan satuan pendidikan tertentu. Hal tersebut sesuai dengan peraturan menteri pendidikan nasional (permendiknas) no 19 tahun 2005 tentang standar nasional pendidikan terutama pada pasal 63 ayat (1), yang bunyinya: penilaian pendidikan pada jenjang pendidikan dasar dan menengah terdiri atas: (a) penilaian hasil belajar oleh pendidik, (b) penilaian hasil belajar oleh satuan pendidikan, dan (c) penialain hasil belajar oleh pemerintah. Untuk tingkat pendidikan dasar, penilaian hasil belajar tersebut berbentuk Ujian Sekolah Berstandar Nasional (USBN) sedangkan untuk jenjang pendidikan menengah, penilaian dalam bentuk ujian nasional (UN).

Evaluasi pendidikan adalah kegiatan menilai yang terjadi dalam kegiatan pendidikan (Daryanto, 2010:6). Evaluasi dilakukan dengan mengumpulkan fakta secara sistematis untuk menentukan dalam kenyataanya terdapat perubahan dan sejauh mana tingkat perubahan kualitas dilakukan untuk menilai tingkat keberhasilan yang dicapai dari sistem pendidikan maupun kebijakan pendidikan yang diterapkan pemerintah agar mengalami perkembangan (Riski et al., 2021:2532).

Banyak kalangan yang mempertanyakan tentang pelaksanaan Ujian Sekolah Berstandar Nasional (USBN) dapat berlangsung dengan baik, mengingat adanya kontrofersi antara setuju dan yang tidak setuju dengan peraturan tersebut. Beberapa kalangan menentang dengan alasan bahwasanya Ujian Sekolah Berstandar Nasional Pendidikan (USBN) tidak mampu mencakup apa yang menjadi tujuan pendidikan, beberapa juga mempertanyakan tentang masalah soal-soal mengingat banyaknya perbedaan.

\section{METODE PENELITIAN}

Penelitian ini merupakan studi literatur dengan menelaah sumber-sumber terkait penghapusan Ujian Sekolah Berstandar Nasional (USBN) (Muslim \& Perdhana, 2017:29). Hasil dari berbagai telaah literatur ini akan digunakan untuk mengevaluasi penghapusan Ujian Sekolah Berstandar Nasional (USBN) serta potensi penelitian selanjutnya di Indonesia. 
4104 EVALUASI PENGHAPUSAN UJIAN SEKOLAH BERSTANDAR NASIONAL (USBN)- Okhaifi Prasetyo, Amanda Ridho Pratomo

DOI: https://doi.org/10.31004/edukatif.v3i6.1281

\section{HASIL DAN PEMBAHASAN PENELITIAN}

\section{Pengertian Ujian Sekolah Berstandar Nasional (USBN)}

Menurut Peraturan Direktur Jenderal Pendidikan Dasar dan Menengah Kementrian Pendidikan dan Kebudayaan Nomor:08/D/HK/2017 Tentang Prosedur Operasional Standar Ujian Sekolah Berstandar Nasional 9POS USBN) pada Pendidikan Dasar dan Menengah tahun Pelajaran 2016/2017. USBN adalah kegiatan pengukuran capaian kompetensi peserta didik yang dilakukan Satuan Pendidikan dengan mengacu pada Standar Kompetensi Lulusan untuk memperoleh pengakuan atas prestasi belajar(Permendiknas, 2016).

Istilah 'berstandar nasional' dalam USBN dimaksudkan: (1) Soal USBN disusun berdasarkan kisi-kisi yangg berlaku secara nasional. Kisi-kisi dikembangkan berdasarkan Standar Isi yang diturunkan menjadi kompetensi dasar sesuai dengan kurikulum yang diterapkan; (2) Soal USBN memiliki soal dari pusat sebanyak 20-25 persen, kecuali untuk mata pelajaran yang ditetapkan di dalam POS USBN; dan (3) USBN dilaksanakan dengan mengacu kepada Prosedur Operasional Standar (POS) USBN yang ditetapkan BSNP (Badan Standar Nasional Pendidikan, 2018:4). Dalam Permendiknas Nomor 82 Tahun 2008, menyebutkan bahwa USBN adalah kegiatan pengukuran dan penilaian kompetensi peserta didik secara nasional. Hasil USBN digunakan sebagai salah satu pertimbangan untuk pemetaan mutu suatu pendidikan, dasar seleksi masuk jenjang pendidikan berikutnya, serta sebagai penentu kelulusan peserta didik dari setuan pendidikan.

Sesuai dengan POS, USBN diselenggarakan oleh penyelenggara USBN Tingkat Pusat, Penyelenggara USBN Tingkat Provinsi, Penyelengggara USBN Tingkat Kabupaten/Kota, dan Penyelenggara USBN Tingkat Sekolah/Madrasah. Unsur-unsur, tugas dan tanggung jawab dari masing-masing penyelenggara terdapat pada POS USBN tahun 2007. Pada POS tersebut dijelaskan tentang tugas dan tanggung jawab masing-masing penyelenggara USBN.

\section{Tujuan Ujian Sekolah Berstandar Nasional (USBN)}

Menurut Arikunto(2009:46) pelaksanaan USBN bertujuan untuk mengukur pencapaian hasil belajar peserta didik selama di sekolah dasar dan menengah. Hal ini dikarenakan soal tes yang dipergunakan sudah distandarkan dan valid sehingga dapat digunakan untuk membandngkan tingkat prestasi peserta didik dalam keterampilan diberbagai bidang studi untuk individu dan kelompok dan antara berbagai sekolah atau kelas serta dapat menilai perkembangan peserta didik dalam suatu periode.

Ujian Sekolah Berstandar Nasional memiliki beberapa tujuan, yaitu (a) Untuk mengukur capaian kompetensi peserta didik yang dilakukan sekolah untuk mata pelajaran dengan mengacu pada Standar Kompetensi Lulusan untuk memperoleh pengakuan atas prestasi belajar, (b) Sebagai sub-sistem penilaian dalam Standar Nasional Pendidikan (SNP) menjadi salah satu tolak ukur pencapaian Standar Nasional Penndidikan dalam rangka penjamian dan peningkatan mutu pendidikan, (c) Untuk meningkatkan mutu ujian sekolah, (d) Untuk meningkatkan kompetensi guru dalam melakukan penilaian, khususnya kemampuan pengembangan soal ujian (Badan Standar Nasional Pendidikan, 2018:4).

\section{Manfaat Ujian Sekolah Berstandar Nasional (USBN)}

Adapun manfaat pada Ujian Sekolah Berstandar Nasional ialah, (a) Digunakan sebagai salah satu kriteria kelulusan, (b) Penguatan Musyawarah Guru Mata Pelajaran (MGMP)/ Kelompok Kerja Guru (KKG)/ Forum Tutor dalam pengembangan dan perakitan naskah soal, (c) Sebagai dasar pemetaan, pembinaan, dan pemberian bantuan kepada satuan pendidikan untuk pemerataan dan peningkatan mutu pendidikan (Badan Standar Nasional Pendidikan, 2018:4)

\section{Persiapan Ujian Sekolah Berstandar Nasional (USBN)}

Menurut (Suwandi, 2013:232-233) persiapan USBN, ialah (a) Persiapan Dinas Pendidikan, provinsi Semua gubernur membuat Surat Keputusan (SK) penyelenggaraan USBN di tingkat Provinsi, (b) Persiapan Dinas Pendidikan Kabupaten/Kota, persiapan yang dilakukan oleh Dinas Pendidikan Kabupaten/Kota bersama Bupati dan Kandepag, (c) Persiapan Sekolah, semua sekolah memberi tambahan pelajaran dari sekolah terutama Matematika, Bahasa Indonesia, dan IPA. Semua sekolah memberi tambahan kesejahteraan guru yang 
melaksanakan pelajaran tambahan, (d) Persiapan Orang Tua Peserta Didik, persiapan untuk menghadapi USBN ini tidak hanya dilakukan oleh sekolah, tetapi juga oleh orang tua peserta didik.

\section{Penyelenggaraan Ujian Sekolah Berstandar Nasional}

Adapun penyelenggaraan ujian sekolah berstandar nasional, ialah (a) USBN diselenggaraan oleh sekolah yang terakreditasi dan dikordinasikan oleh Dinas Pendidikan Provinsi, Kabupaten/Kota sesuai dengan kewenangannya, (b) Sekolah membentuk panitia USBN sekaligus sebagai panitia US yang ditetapkan dengan keputusan kepala sekolah dan dilaporkan kepada Dinas Pendidikan provinsi, kabupaten/Kota sesuai dengan kewenangannya, (c) Panitia USBN dan US terdiri atas ketua, sekretaris, bendahara, dan seksi-seksi sesuai dengan kewenangannya, (d) Panitia USBN dan US bertanggung jawab penuh atas kerahasian, keamanan, dan kelancaran penyelenggaraan USBN dan US mulai dari persiapan, pelaksanaan, sampai dengan pelaporan, (e) Panitia USBN dan US bertanggung jawab penuh atas pengamanan naskah, pelaksanaan, dan kenyamanan serta ketertiban ruang dan lingkungan sekitar tempat ujian, (f) Setiap anggota panitia USBN dan US menandatangani pakta integritas untuk menjaga kerahasian penyelenggaraan kegiatan ujian dengan jujur, $(\mathrm{g})$ Ketentuan lebih lanjut mengenai US diatur dala POS US yang ditetapkan oleh sekolah(Ikhsan et al., 2018:211-212).

\section{Mekanisme Penyusunan Soal Ujian Sekolah Berstandar Nasional (USBN)}

Menurut Ikhsan et al.(2018:212)mekanisme penyusunan soal USBN, ialah (a) BNSP menetapkan kisikisi, (b) Kementrian menetapkan POS USBN, (c) Kementerian menyusun kisi-kisi USBN untuk semua mata pelajaran kecuali pendidikan agama dan budi pekerti, (d) Kementrian menyusun dan menetapkan soal sebanyak 20\%-25\% soal USBN untuk semua mata pelajaran kecuali pendidikan agama dan budi pekerti, (e) Dinas pendidikan Provinsi/Kabupaten/Kota sesuai dengan kewenangan menetapkan MGMP yang akan menyusun soal USBN, (f) MGMP menyusun soal USBN sebanyak 75\%-80\% sejumlah paket yang ditentukan untuk masing-masing mata pelajaran, (g) Kementerian menyerahkan 20\%-25\% soal USBN ke Dinas Pendidikan Provinsi/Kabupaten/Kota sesuai dengan kewenanganya untuk selanjutnya diserahkan kepada MGMP yang telah ditetapkan oleh Dinas Pendidikan Provinsi/Kabupaten/Kota untuk menyusun naskah soal USBN, (h) MGMP merakit soal USBN sejumlah paket yang ditentukan untuk masing-masing mata pelajaran, (i) MGMP menyerahkan naskah soal USBN berikut kelengkapannya ke MKKS dengan diketahui oleh Dinas Pendidikan Provinsi/Kabupaten/Kota, (j) Ketua MKKS mendistribusikan ke kepala sekolah masing-masing, (k) Sekolah mengadakan naskah soal USBN berikut kelengkapanya sesuai dengan jumlah yang dibutuhkan.

\section{Penghapusan Ujian Sekolah Berstandar Nasional (USBN)}

Alasan Mendikbud menghapus UN dan USBN, menurut Nasiem keputusan menghapus UN dan USBN diambil setelah berdiskusi dengan pihak wali murid, guru, dan praktisi pendidikan. Berdasarkan survei dan diskusi bersama dengan unsur orang tua, peserta didik, guru, praktisi pendidikan, dan kepala sekolah. Materi UN dan USBN terlalu padat sehingga cenderung mengajarkan materi dan menghafal materi, bukan kompetensi. Selain itu UN dan USBN juga membuat peserta didik dan guru stres, dan hal itu mengubah indikator keberhasilan siswa sebagai individu. UN dan USBN hanya menilai satu aspek saja yaitu kognitifnya, bahkan enggak semua aspek kognitif kompetensi di tes, dan lebih banya ke penguasaan materinya dan belum menyentuh karakter peserta didik secara lebih holistik (Halik, 2019).

Kementrian Pendidikan sudah menerbitkan Permendikbud Nomor 43 tahun 2019. Dalam Permendikbud tersebut, diatur mengenai mekanisme penyelenggaraan Ujian Nasional. Berdasarkan Permendikbud tersebut, Ujian Sekolah Berstandar Nasional (USBN) akan dihapuskan. Ketua Badan Standar Nasional Pendidikan (BSNP) Abdul Mu'ti mengatakan buat tahun ini USBN tidak akan dilakukan. "Tidak terdapat lagi USBN dan karenanya maka BSNP tidak menerbitkan pos USBN, yang berlaku nanti ketika ujian sekolah. Nantinya, bentuk penyelenggaraan ujian sekolah tersebut sudah tidak mengacu pada Kemendikbud. Tapi akan diserahkan kepada pihak sekolah "Pelaksanaan ujian itu dilaksanakan oleh masing-masing satuan pendidikan" (Badan Standar Nasional Pendidikan, 2020). 
4106 EVALUASI PENGHAPUSAN UJIAN SEKOLAH BERSTANDAR NASIONAL (USBN)- Okhaifi Prasetyo, Amanda Ridho Pratomo

DOI: https://doi.org/10.31004/edukatif.v3i6.1281

\section{Reaksi Penghapusan Ujian Sekolah Berstandar Nasional (USBN)}

Penghapusan Prosedur Operasional Standar (POS) Ujian Sekolah Berstandar Nasional (USBN) banya mengundang reaksi dari beragam lingkungan sekolah. Dampak dari penghapusan USBN, pihak sekolah mempunya kewenangan penuh atas pembuatan soal sendiri dalam penyelenggaraan ujian. Wakil Kepala Sekolah Bidang Kurikulum Sekolah Menengah Atas Negeri 10 Jakarta, Rahmat Apriyanto mengungkap sedikit kekhawatiran. Sebab ketika USBN dihapus, mestinya ada beberapa standarisasi bagi pencapaian peserta didik untuk dapat dinyatakan lulus yang ditetapkan oleh Kemendikbud. Kendati demikian beliau menyambut baik maksud dari Menteri Pendidikn Nadiem, sekolah menangkap iktikad Mendikbud untuk menekankan kemampuan peserta didik, bukan pada pada pengerjaan soal dengan cara menghafal saja. Selain tenaga pendidik, penghapusan USBN menimulkan beberapa rekasi dari peserta didik sekolah. Audri, siswi SMAN 10 Jakarta menilai dengan dihapuskanya USBN tahun ini akan mempermudah dirinya dalam mengerjakan soal ujian karena wewenang pembuatan soal dari pihak sekolahnya sendiri (CNN Indonesia, 2020).

Tetapi tidak seperti yang lain, Ibu Siti dari orang tua peserta didik, beliau berpendapat kalau USBN dihapuskan kuatir. Sebab jika USBN dihapuskan menurut beliau semangat belajar anak-anak jadi menurun. Dengan adanya USBN maka ada motivasi dan semangat dari orang tua peserta didik untuk mendorong anakanak belajar. Memang dengan tidak adanya USBN, peserta didik akan menjadi lebih santai belajar sehingga tidak ada target belajar peserta didik (Nugroho, 2019).

Sedangkan menurut Kepala SMA Khadijah Wonokromo Surabaya, Bapak Ghofar mengatakan pembuatan soal-soal untuk mengganti USBN ini bagi sekolah sebenarnya tidak menjadi masalah. Namun, yang perlu diingat adalah, jika sekolah tidak memiliki komitmen yang baik, maka ini akan menjadi sebuah formalitas semata. "kalau sekolah memiliki komitmen untuk meningkatkan mutu pendidikan, jelas soal-soal yang dibuat akan berbobot. Tapi kalau tidak, maka akan dibuat asal-asalan. Asal peserta didiknya bisa lulus. Ini jadi tidak baik, akan menurunkan kualitas lulusan. Karena pembuatan soal-soal seharusnya tetap dikontrol pihak-pihak terkait yang memiliki kepentingan dengan masalah ini, sebab ini berbicara kualitas (Duta.co, 2020).

\section{Evaluasi Penghapusan Ujian Sekolah Berstandar Nasional (USBN)}

Berdasarkan pendapat dari para ahli, guru, peserta duduk, orang tua peserta didik, saya mendudukung keputusan penghapusan USBN. Untuk saat ini Ujian Sekolah Berstandar Nasional memang menjadi standarlisasi kelulusan peserta didik di Indonesia. Utuh pembaharuan untuk sistem pendidikan di era 4.0, yang mana pendidikan bersifat open sorce, merdeka, dan bukan lagi berdasarkan standar serta keragaman, tapi berdasarkan minat dan bakat masing-masing peserta didik. Dengan dihapusnya USBN, sekolah-sekolah bisa menjalankan proses pendidikan dengan menyesuaikan kondisi wilayah masing-masing, apalagi Indonesia sangat beragam degan kultur yang berbeda di setiap wilayahnya.

Meski USBN di hapuskan masih banyak yang harus diperbaiki oleh pihak Satuan Pendidikan, khusunya dalam pengawasan dan standar pembuatan soal. Dengan dihapuskannya POS maka tidak ada standar soal dalam ujian sekolah, hal ini yang banyak ditakutkan oleh pengamat pendidikan serta guru itu sendiri. Karena jika tidak adanya standardisasi maka ditakutkan pihak sekolah akan membuat soal dengan asal-asal tanpa memikirkan kualitas soal itu sendiri. Selain perbaikan di bidang standar soal, masih banyak lagi yang harus diperbaiki, mulai dari pelaksanaan, pelatihan-pelatihan guru dalam pembuatan soal serta tujuan yang jelas dari pengganti USBN itu sendiri.

\section{KESIMPULAN}

USBN adalah kegiatan pengukuran capaian kompetensi peserta didik yang dilakukan Satuan Pendidikan dengan mengacu pada Standar Kompetensi Lulusan untuk memperoleh pengakuan atas prestasi belajar. 
4107 EVALUASI PENGHAPUSAN UJIAN SEKOLAH BERSTANDAR NASIONAL (USBN)- Okhaifi Prasetyo, Amanda Ridho Pratomo

DOI: https://doi.org/10.31004/edukatif.v3i6.1281

Mendikbud Nadiem memiliki alasan dalam penghapusan USBN, karena materi terlalu padat sehingga cenderung mengajarkan materi dan menghafal materi, bukan kompetensi. Selain itu USBN juga membuat peserta didik dan guru stres, dan hal itu mengubah indikator keberhasilan siswa sebagai individu. Berdasarkan pendapat dari para ahli, guru, peserta duduk, orang tua peserta didik, saya mendudukung keputusan penghapusan USBN. Untuk saat ini Ujian Sekolah Berstandar Nasional memang menjadi standarlisasi kelulusan peserta didik di Indonesia. Untuk pembaharuan untuk sistem pendidikan di era 4.0, yang mana pendidikan bersifat open sorce, merdeka, dan bukan lagi berdasarkan standar serta keragaman, tapi berdasarkan minat dan bakat masing-masing peserta didik.

\section{DAFTAR PUSTAKA}

Arikunto, S. (2009). Dasar-Dasar Evaluasi Pendidikan. Bumi Aksara.

Badan Standar Nasional Pendidikan. (2018). Tanya Jawab Pelaksanaan Ujian Sekolah Berstandar Nasional (Usbn) Tahun Pelajaran 2017/2018. Badan Standar Nasional Pendidikan.

Badan Standar Nasional Pendidikan. (2020). Bsnp: Tahun 2020 Usbn Dihapus. Bsnp-Indonesia.Org. Https://Bsnp-Indonesia.Org/2020/01/Bsnp-Tahun-2020-Usbn-Dihapus/

Cnn Indonesia. (2020). Ragam Reaksi Usbn 2020 Dihapus: Guru Khawatir, Murid Senang. Cnnindonesia.Com. Https://Www.Cnnindonesia.Com/Nasional/20200123073159-20-467875/RagamReaksi-Usbn-2020-Dihapus-Guru-Khawatir-Murid-Senang

Daryanto. (2010). Evaluasi Pendidikan. Rineka Cipta.

Duta.Co. (2020). Usbn 2020 Dihapus, Ini Komentar Sekolah Di Surabaya. Duta.Co. Https://Duta.Co/Usbn2020-Dihapus-Ini-Komentar-Sekolah-Di-Surabaya

Farida, Y. T. (2000). Evaluasi Program. Rineka Cipta.

Halik, A. (2019). Ini Alasan Mendikbud Nadiem Hapus Ujian Nasional 2021. Beritasatu.Com. Https://Www.Beritasatu.Com/Nasional/590122inialasanmendikbud-Nadiem-Hapusujiannasional-2021

Ikhsan, A. M., Bilqis, A. N. S., \& Rahmawati, W. I. (2018). Persepsi Guru Terhadap Pelaksanaan Usbn 2017 Di Sman 16 Makassar. Prosiding Seminar Nasional "Penguatan Pendidikan Karakter Pada Siswa Dalam Mengahadapi Tantangan Global” Universitas Maria Kudus.

Muslim, M. I., \& Perdhana, M. S. (2017). Glass Ceiling: Sebuah Studi Literatur. Jurnal Bisnis Strategi, 26(1), $28-38$.

Ngalim, P. (1994). Prinsip-Prinsip Dan Teknik Evaluasi Pengajaran. Remaja Rosdakarya.

Nugroho, E. (2019). Usbn Sd Dihapuskan Januari 2020, Begini Reaksi Orangtua Siswa. Banjarmasin.Tribunnews.Com. Https://Banjarmasin.Tribunnews.Com/2019/12/26/Usbn-Sd-DihapuskanJanuari-2020-Begini-Reaksi-Orangtua-Siswa

Permendiknas. (2016). Peraturan Direktur Jenderal Pendidikan Dasar Dan Menengah Kementrian Pendidikan Dan Kebudayaan Nomor:08/D/Hk/2017 Tentang Prosedur Operasional Standar Ujian Sekolah Berstandar Nasional 9pos Usbn) Pada Pendidikan Dasar Dan Menengah Tahun Pelajaran 2016/201. Kemdikbud.

Riski, H., Rusdinal, R., \& Gistituti, N. (2021). Kepemimpinan Kepala Sekolah Di Sekolah Menengah Pertama. Edukatif: Jurnal Ilmu Pendidikan, 3(6), 3531-3537.

Suwandi. (2013). Evaluasi Pelaksanaan Ujian Akhir Sekolah Berstandar Nasional (Uasbn). Jurnal Pendidikan Teknologi Dan Kejuruan, 21(3).

Waruwu, M. (2021). Analisis Implementasi Prinsip Empowerment Pada Kepemimpinan Kepala Sekolah. Edukatif: Jurnal Ilmu Pendidikan, 3(6), 3721-3727. 